Care: Jurnal Ilmiah Ilmu Kesehatan Vol.8, No.3, 2020, hal 346-360

Tersedia online di https://jurnal.unitri.ac.id/index.php/care

ISSN 2527-8487 (online)

ISSN 2089-4503 (cetak)

\title{
PENGARUH TINGKAT STRES TERHADAP MEKANISME KOPING PASIEN KANKER BERBASIS MANAJEMEN TERAPI KANKER
}

\author{
Yesiana Dwi Wahyu Werdani \\ Universitas Katolik Widya Mandala Surabaya \\ E-mail: ywerdani@yahoo.com
}

\begin{abstract}
The management of cancer therapy is useful to improve the survival of cancer patients, but it has a physical impact on various functions of the body's organs. It can lead to stress and affect individual coping mechanisms. The aim of this study was to analyze the effect of stress levels on coping mechanisms of cancer patients based on cancer therapeutic management. This study used a mix method design and sequential explanatory approach. The population was cancer patients at the Indonesian Cancer Foundation, East Java Branch, Surabaya. The number of sample were 32 patients taken by total sampling method. The instrument used perceived stress scale and coping strategies inventory short form. The result of ordinal regression test and nagelkerle's pseudo R-Square in chemotherapy group 0.013 and $\mathrm{R} 0.621$, in radiation group 0.016 and $\mathrm{R} 0.597$, in chemoradiotherapy group 0.010 and $\mathrm{R} 0.737$. It means that stress levels has a significant effect on individual coping mechanisms in all cancer therapeutic management groups. On the qualitative results showed that stress and maladaptive coping mechanisms caused by side effects of therapy, financial, relationships with caregiver was less harmonious, less able to think, positively. The complexity of therapeutic stressors and the presence of poorly managed of external factors made respondents more likely to have maladaptive coping mechanisms.
\end{abstract}

Keywords: Stress levels; coping mechanisms; cancer therapy management.

\begin{abstract}
ABSTRAK
Manajemen terapi kanker bermanfaat untuk meningkatkan kelangsungan hidup pasien kanker, namun memberikan dampak fisik terhadap berbagai fungsi organ tubuh.Hal ini dapat memicu timbulnya stres dan berpengaruh terhadap mekanisme koping individu. Tujuan penelitian menganalisis pengaruh tingkat stres terhadap mekanisme koping pasien kanker berbasis manajemen terapi kanker. Penelitian ini menggunakan mix method design pendekatan sequential explanatory. Populasi adalah pasien kanker di Yayasan Kanker Indonesia Cabang Jawa Timur Surabaya, dengan jumlah sampel 32 orang yang diambil dengan teknik total sampling. Instrumen yang digunakan perceived stress scaledancoping strategies inventory short form. Uji Regresi ordinal dan hasil pseudo R-Square Nagelkerle's pada kelompok kemoterapi 0.013 dan R 0.621, kelompok radiasi 0.016 dan R 0.597, kelompok
\end{abstract}

Cara mengutip: Werdani, Y.D. Wahyu. (2020). Pengaruh Tingkat Stres Terhadap Mekanisme Koping Pasien Kanker Berbasis Manajemen Terapi Kanker.Care:Jurnal Ilmiah Ilmu Kesehatan, 8(3), 346-360 
kemoradioterapi 0.010 dan $\mathrm{R}$ 0.737, yang berarti bahwa tingkat stres memberikan pengaruh yang bermakna terhadap mekanisme koping individu pada semua kelompok manajemen terapi kanker. Pada hasil kualitatif timbulnya stres dan mekanisme koping maladaptif diakibatkan oleh efek samping terapi, finansial, hubungan dengan pendamping kurang harmonis, kurang mampu berpikir positif.Kompleksnya stresor akibat terapi dan adanya faktor eksternal yang kurang dikelola dengan baik menyebabkan responden lebih cenderung memiliki mekanisme koping maladaptif.

Kata Kunci : Tingkat Stres; Mekanisme koping; Manajemen terapi kanker.

\section{PENDAHULUAN}

Kanker merupakan salah satu penyakit yang memiliki modalitas terapi yang kompleks dan penuh resiko.Terapi yang sering dilakukan untuk mengatasi pertumbuhan sel kanker adalah operasi, kemoterapi, radiasi, kemoradioterapi ataupun terapi hormon.Manajemen terapi kanker yang tepat dapat memperpanjang hidup pasien (Siegel, Naishadham, \& Jemal, 2012). Berdasarkan penelitian kohort terhadap 32.502 wanita dengan kanker payudara pasca kemoterapi memiliki tingkat kelangsungan hidup yang lebih tinggi yaitu mencapai 5 tahun sebanyak 92.1\% dan 10 tahun sebanyak 81.9\% (Rossi et al., 2015). Penelitian lain terhadap 6.296 pasien kanker esofagus stadium IV mendapatkan hasil sejumlah $31 \%$ pasien yang menerima kemoterapi dan radioterapi secara signifikan dapat meningkatkan angka survival rate dengan hasil p<001 (Moreno et al., 2017).
Secara keseluruhan terdapat 14,1 juta kasus baru dan 8,2 juta kematian pada tahun 2012 pada tingkat dunia. Kanker yang paling umum didiagnosis adalah kanker paru (1,82 juta), kanker payudara (1,67 juta), dan kanker kolorektal (1,36 juta) (Ferlay et al., 2015). Adapun penatalaksanaan kanker di Indonesia berupa kemoterapi sebesar $24.9 \%$, radiasi $17.3 \%$, operasi $61.8 \%$ dan terapi lain-lain $24.1 \%$ (Badan Penelitian dan Pengembangan Kesehatan, 2018).

Terapi kanker baik berupa kemoterapi, radiasi, kemoradioterapi maupun terapi hormonal dapat berfungsi untuk meningkatkan survival rate, namun juga memiliki berbagai efek samping yang menimbulkan perubahan pada kondisi fisik. Pada pasien kanker pasca terapi terdapat 85\% mengeluhkan kelelahan, $74 \%$ diare dan 74\% mengalami konstipasi (Pearce et al., 2017). Munculnya berbagai efek samping dari terapi kanker dapat menjadi stresor bagi pasien yang memicu 
timbulnya stres. Salah satu penyebab stres psikologis adalah adanya stres fisik seperti penyakit dan gejala-gejala yang menyertainya, yang dapat menyebabkan tubuh tidak mampu menahannya.Berdasarkan metaanalisis penelitian ditemukanhasil bahwa tingkat cancer related fatigue (CRF) yang tinggi dapat menyebabkan timbulnya depresi dan kecemasan yang lebih tinggi pula (Seo, Oh, Seo, \& Kim, 2006).

Stres psikologis yang muncul pada individu harus dikelola dalam bentuk mekanisme koping adaptasi (Mukwato, Mweemba, Makukula, \& Makoleka, n.d.). Strategi koping maladaptif seperti penolakan dan menyalahkan diri sendiri dapat memberikan pengaruh yang buruk terhadap kualitas hidup seseorang (Nipp et al., 2016). Tujuan penelitian ini adalah untuk menganalisis pengaruh tingkat stres terhadap mekanisme koping pasien kanker berbasis manajemen terapi kanker.

\section{METODE PENELITIAN}

Penelitian ini menggunakan mix method design dengan pendekatan sequential explanatory dan pada desain kuantitatif menggunakan rancangan cross sectional design.Populasi adalahseluruh pasien kanker di Yayasan Kanker Indonesia Cabang Jawa Timur. Surabaya. Jumlah sampel sebanyak 32 pasien yang diambil dengan teknik total sampling. Ada 2 instrumen yang digunakan yaitu perceived stress scale (PSS) yang telah diuji validitas dengan $r=0.429-1$ dan uji reliabilitas dengan Cronbach's Alpha $\alpha=0.950$. Kuesioner coping strategies inventory (CSI) short form dengan hasil uji validitas $\mathrm{r}=$ 0.715 - 0.959 dan uji reliabilitas dengan menggunakan Cronbach's Alpha $\alpha=0.988$. Kedua instrumen tersebut terbukti valid dan reliable.

Sebelum pelaksanaan penelitian, telah dilakukan langkah-langkah etik dengan cara memberikan penjelasan kepada calon responden terkait dengan tujuan, manfaat, prosedur penelitian, dan resiko yang mungkin terjadi dari penelitian ini. Calon responden yang berkenan terlibat dalam penelitian ini selanjutnya diberikan informed consent sebagai bentuk persetujuan tanpa paksaan.

Penelitian ini dilakukan melalui 2 tahap yaitu penyebaran kuesioner PSS dan CSI yang dilanjutkan dengan deepinterview terkait dengan detail gambaran tingkat stres yang menyebabkan responden melakukan bentuk mekanisme koping tertentu. Data kuantitatif diuji statistik dengan regresi ordinal $\alpha<0.05$, 
sedangkan data hasil deepinterview disajikan

sebagai temuan pernyataan.

\section{HASIL}

Tabel 1. Karakteristik Data Demografi Responden

\begin{tabular}{|c|c|c|c|c|c|c|c|}
\hline \multirow[t]{2}{*}{ Data Demografi } & \multirow[t]{2}{*}{ Kategori } & \multicolumn{2}{|c|}{$\begin{array}{l}\text { Kemoterapi } \\
(\mathrm{n}=12)\end{array}$} & \multicolumn{2}{|c|}{$\begin{array}{l}\text { Radiasi } \\
(\mathrm{n}=8)\end{array}$} & \multicolumn{2}{|c|}{$\begin{array}{l}\text { Kemoradioterapi } \\
\quad(\mathrm{n}=12)\end{array}$} \\
\hline & & $\mathrm{n}$ & $\%$ & $\mathrm{n}$ & $\%$ & $\mathbf{N}$ & $\%$ \\
\hline \multirow[t]{5}{*}{ Usia } & $26-35$ tahun & 2 & 16.7 & 1 & 12.5 & 0 & 0 \\
\hline & $36-45$ tahun & 2 & 16.7 & 0 & 0 & 1 & 8.3 \\
\hline & $46-55$ tahun & 3 & 25.0 & 2 & 25.0 & 5 & 41.7 \\
\hline & $56-65$ tahun & 4 & 33.3 & 4 & 50.0 & 4 & 33.3 \\
\hline & $>65$ tahun & 1 & 8.3 & 1 & 12.5 & 2 & 16.7 \\
\hline \multirow[t]{2}{*}{ Jenis kelamin } & Perempuan & 9 & 75.0 & 7 & 87.5 & 10 & 83.3 \\
\hline & Laki-laki & 3 & 25.0 & 1 & 12.5 & 2 & 16.7 \\
\hline \multirow[t]{4}{*}{ Lama terdiagnosa kanker } & $<1$ tahun & 6 & 50.0 & 5 & 62.5 & 7 & 58.4 \\
\hline & $1-<2$ tahun & 4 & 33.3 & 2 & 25 & 3 & 25.0 \\
\hline & $2-<3$ tahun & 2 & 16.7 & 1 & 12.5 & 1 & 8.3 \\
\hline & $>3$ tahun & 0 & 0 & 0 & 0 & 1 & 8.3 \\
\hline \multirow[t]{3}{*}{ Stadium kanker } & II & 5 & 41.7 & 6 & 75.0 & 4 & 33.3 \\
\hline & III & 6 & 50.0 & 2 & 25.0 & 6 & 50.0 \\
\hline & IV & 1 & 8.3 & 0 & 0 & 2 & 16.7 \\
\hline \multirow[t]{4}{*}{ Jenis kanker } & Kanker payudara & 5 & 41.7 & 4 & 50 & 7 & 58.4 \\
\hline & Kanker servix & 4 & 33.3 & 3 & 37.5 & 4 & 33.3 \\
\hline & Kanker usus & 2 & 16.7 & 0 & 0 & 1 & 8.3 \\
\hline & Kanker paru & 1 & 8.3 & 1 & 12.5 & 0 & 0 \\
\hline
\end{tabular}

Pada Tabel 1 dapat dideskripsikan bahwa pada kelompok kemoterapi dan radioterapi mayoritas responden berusia 56 - 65 tahun (lansia akhir) dengan prosentase bervariasi yaitu pada kelompok kemoterapi $33.3 \%$ dan pada kelompok radiasi $50 \%$, sedangkan pada kelompok kemoradioterapi mayoritas responden berada pada rentang usia 46 55 tahun (lansia awal) yaitu sebesar 41.7\%. Pada ketiga kelompok didominasi oleh responden perempuan sebesar 75\% pada kelompok kemoterapi, $87.5 \%$ pada kelompok radiasi dan $83.3 \%$ pada kelompok kemoradioterapi. Berdasarkan lama terdiagnosa kanker, responden pada semua kelompok mayoritas baru terdiagnosa kanker $<1$ tahun yaitu pada kelompok kemoterapi sebesar 50\%, pada kelompok radiasi $62.5 \%$ dan pada kelompok kemoradioterapi 58.4\%. Berdasarkan stadium kanker terdapat hasil yang bervariasi, pada kelompok kemoterapi dan kelompok kemoradioterapi mayoritas responden berada pada kanker stadium III dengan jumlah prosentase yang sama yaitu masing-masing adalah 50\%, sedangkan pada kelompok radiasi didominasi oleh responden dengan kanker stadium II yaitu sebesar 75\%. Berdasarkan jenis kanker, pada ketiga kelompok semuanya 
mayoritas menderita kanker payudara 41.7\%, pada kelompok radiasi 50\% dan yaitu pada kelompok kemoterapi sebesar pada kelompok kemoradioterapi $58.4 \%$.

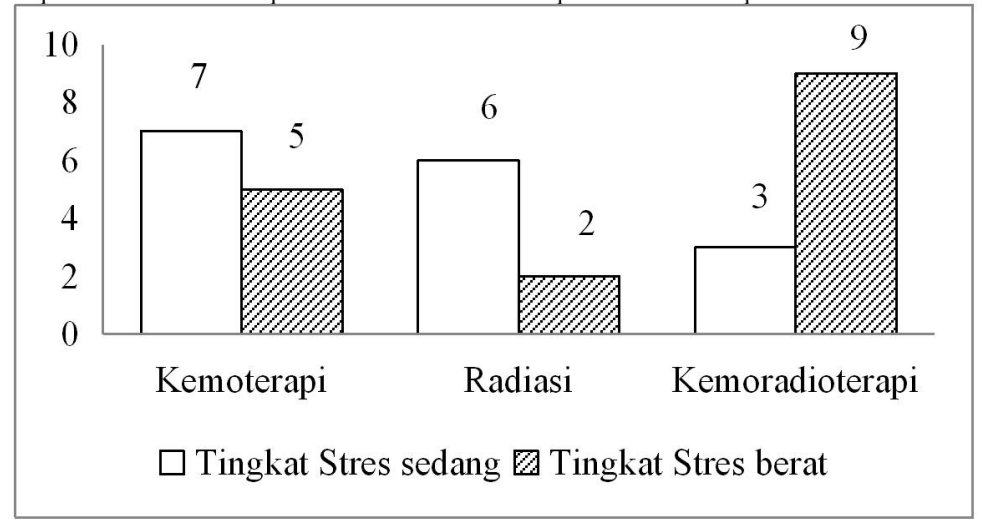

Gambar 1. Tingkat Stres Responden Berbasis Manajemen Terapi Kanker

Pada Gambar 1 dapat dideskripsikan bahwa pada kelompok yang mendapatkan manajemen kemoterapi dan radiasi, mayoritas responden mengalami tingkat stres sedang yaitu pada kelompok dan pada kelompok radiasi sebanyak 6 responden (75\%). Tingkat stres berat didominasi oleh responden pada kelompok kemoradioterapi yaitu sebanyak 9 orang $(75 \%)$.

kemoterapi sebanyak 7 responden $(58.3 \%$ )

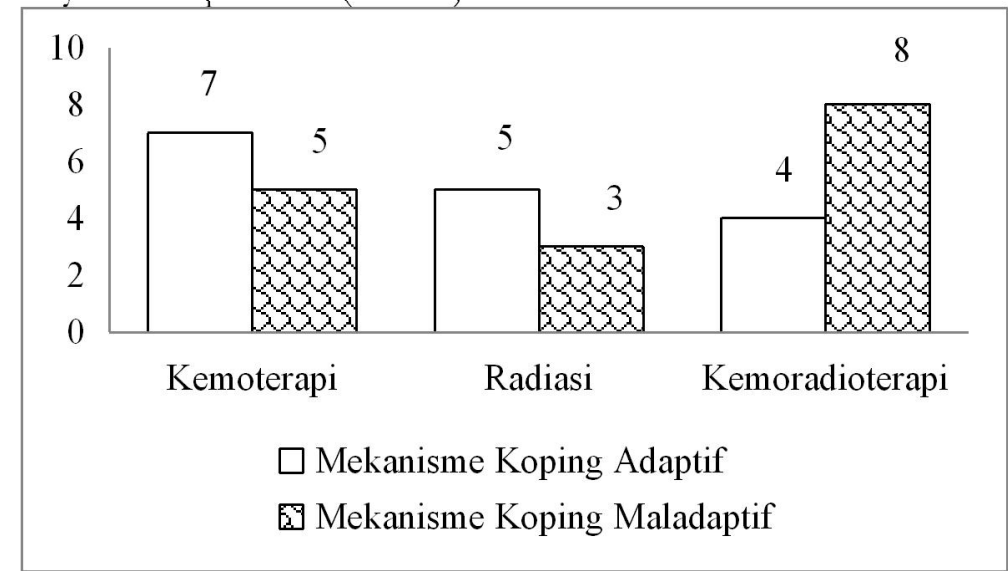

Gambar 2. Mekanisme Koping Responden Berbasis Manajemen Terapi

Pada Gambar 2 dapat dideskripsikan bahwa pada kelompok kemoterapi dan kelompok radiasi didominasi oleh responden yang memiliki mekanisme koping adaptif, yaitu sebesar 7 responden (58.3\%) pada kelompok kemoterapi dan sebanyak 5 responden (62.5\%) pada kelompok radiasi. Mayoritas responden pada kelompok kemoradioterapi memiliki mekanisme koping yang maladaptif yaitu sebanyak 8 responden (66.6\%). 
Tabel 2. Hasil uji statistik regresi ordinal pengaruh tingkat stres terhadap mekanisme koping berbasis manajemen terapi kanker

\begin{tabular}{ccc}
\hline Kelompok Responden & Uji Regresi Ordinal & Pseudo R-Square Nagelkerke \\
\hline Kemoterapi & 0.013 & 0.621 \\
Radiasi & 0.016 & 0.597 \\
Kemoradiasi & 0.010 & 0.737 \\
\hline
\end{tabular}

Berdasarkan Tabel 2 dapat dideskripsikan bahwa tingkat stres pasien kanker dapat memberikan pengaruh yang bermakna terhadap mekanisme koping, yang dibuktikan dengan nilai p pada ketiga kelompok $<$ 0.05.Besarnya pengaruh tingkat stres terhadap mekanisme koping pada masing-masing kelompok berbedabeda. Pada kelompok kemoterapi, tingkat stres berpengaruh sebesar $62.1 \%$ terhadap mekanisme koping, pada kelompok radiasi berpengaruh 59.7\% dan pada kelompok kemoradioterapi berpengaruh $73.7 \%$. Dari ketiga kelompok tersebut, responden pada kelompok kemoradioterapi memiliki tingkat stres yang memberikan pengaruh terbesar pada mekanisme koping.

Hasil deepinterview dengan responden didapatkan data kualitatif sebagai berikut mayoritas responden pada ketiga kelompok menyatakan stres timbul akibat efek samping pengobatan yaitu rasa letih yang berlebihan, nyeri hebat, mual muntah, dan sembelit. Penyebab lain yang menyebabkan responden merasa stres adalah masalah finansial akibat pasien berhenti bekerja karena penyakitnya, adanya ketakutan yang tinggi terhadap munculnya kembali sel kanker setelah pengobatan, adanya hubungan dengan pendamping yang kurang harmonis dan gambaran kematian yang menakutkan.

Mayoritas responden sudah berusaha untuk pasrah kepada Tuhan dan lebih religious dalam menghadapi berbagai keluhan fisik yang dirasakan, namun bila keluhan datang bertubi-tubi menyebabkan responden menjadi putus asa, mudah marah dan sering menyalahkan diri sendiri dan orang lain terutama marah kepada pendamping. Responden sering bersitegang dengan para pendamping karena merasa pendamping kurang sabar dalam merawat mereka.Responden juga kurang mampu mengambil hal positif dari keadaannya. Hal ini menyebabkan mayoritas responden enggan untuk berbagi cerita dengan pendamping, dan kurang relaks 
pada setiap situasi. Ini semua mengakibatkan mekanisme koping responden menjadi maladaptif.Namun adapula responden yang memiliki hubungan baik dengan pendamping dan lebih religious serta memiliki kepasrahan yang tinggi kepada Tuhan.

\section{PEMBAHASAN}

\section{Tingkat Stres}

Berdasarkan hasil penelitian yang diperoleh tidak ada satupun kelompok yang mengalami tingkat stres ringan.Hanya terdapat dua jenis tingkat stres yang dialami oleh responden pada ketiga kelompok yaitu tingkat stres sedang dan tingkat stres berat.Tingkat stres sedang mayoritas dialami oleh responden pada kelompok kemoterapi dan radiasi, sedangkan tingkat stres berat mayoritas dialami oleh responden pada kelompok kemoradioterapi.Penyakit kronis yang sulit disembuhkan seperti penyakit kanker merupakan pemicu timbulnya gangguan psikologis berupa stres, kecemasan maupun depresi. Penelitian yang dilakukan kepada 150 pasien dengan berbagai jenis kanker mendapatkan hasil bahwa $29.3 \%$ pasien mengalami kecemasan ringan, 16.7\% mengalami kecemasan simtomatik, 26.7\% mengalami depresi ringan dan $21.3 \%$ mengalami depresi simtomatik
(Nikbakhsh, Moudi, Abbasian, \& Khafri, 2014). Tingkat stres dapat dipengaruhi pula oleh faktor usia. Pada penelitian ini ketiga kelompok didominasi oleh responden lansia yang berada pada rentang usia 46 - 55 tahun (lansia awal) dan 56 - 65 tahun (lansia akhir). Kecemasan dan depresi sering terjadi pada populasi lansia yang mengalami gangguan fisik dalam waktu yang lama (Kang et al., 2017). Hal ini senada dengan penelitian lain yang menyebutkan bahwa responden yang berusia dewasa tua dan lansia lebih rentan mengalami emosi negatif yang dipengaruhi oleh derajat keparahan stresor (Scott, Sliwinski, \& Blanchard-Fields, 2013).

Penyakit kanker memiliki stadium yang menunjukkan derajat keparahan.Pada penelitian ini kelompok kemoterapi dan kemoradioterapi mayoritas respondennya menderita kanker pada stadium III, sedangkan pada kelompok radiasi didominasi oleh responden yang mengalami kanker stadium II. Pasien dengan kanker stadium II dan III sel kanker sudah mulai mengalami metastasis dan keluar dari sel target (National Cancer Institute, 2015). Metastasis dapat disebabkan oleh terlepasnya sel tumor ke dalam aliran limfatik dan membentuk sel kanker yang baru (Martin et al., 2014). 
Upaya medis yang sering dilakukan untuk mematikan sel kanker dan menghambat proses metastasis adalah melalui manajemen terapi kanker. Pada penelitian ini semua responden mendapatkan modalitas terapi kanker berupa kemoterapi (37.5\%), radiasi (25\%) dan kemoradioterapi (37.5\%).Responden yang mendapatkan terapi kombinasi berupa kemoradioterapi memiliki tingkat stres yang berat, hal ini dapat dikaitkan dengan efek samping yang ditimbulkan dari terapi tersebut, yang dapat menyebabkan gangguan secara fisik. Kombinasi kemoterapi dan radiasi atau sering disebut dengan kemoradioterapi merupakan salah satu terapi yang efektif untuk mendapatkan hasil yang optimal (Geng, Paganetti, \& Grassberger, 2017). Efek samping yang ditimbulkan dari kemoterapi dan radiasi yaitu terjadinya perubahan fisik yang dapat mengganggu aktivitas pasien sehari-hari (Bongers et al., 2017). Penelitian yang dilakukan pada 100 pasien kanker menyatakan bahwa kemoterapi memiliki berbagai efek samping yaitu $95 \%$ berupa kelemahan fisik, 90\% kelelahan, 43\% nyeri kepala persisten, $76 \%$ alopesia, $77 \%$ nausea $75 \%$ vomiting, 31\% diare, dan 40\% abdominal cramps(Aslam et al., 2014).Keluhan fisik yang dirasakan pasien kanker yang timbul pada saat terdiagnosa kanker, saat sedang mendapat terapi kanker maupun pasca terapi kanker dapat memicu timbulnya stres psikologis. Pasien kanker menunjukkan adanya perubahan emosi dan perilaku pada saat terdiagnosa kanker dan selama proses terapi. Perubahan tersebut meliputi adanya kecemasan, depresi yang dapat memperburuk kualitas hidup (İzci, İlgün, Fındıklı, \& Özmen, 2016).

Hal lain yang dapat dikaitkan dengan tingkat stres pada penelitian ini adalah jenis kanker yang dialami responden. Mayoritas responden pada ketiga kelompok mengalami kanker payudara.Payudara merupakan salah satu mahkota kebanggaan bagi wanita, bila payudara mengalami sakit dan harus diangkat ataupun mengalami perlukaan akibat kanker dapat meningkatkan rasa stres pada individu tersebut. Penelitian pada 100 pasien kanker payudara pasca mastektomi didapatkan hasil bahwa mayoritas pasien mengalami harga diri rendah dan depresi (Ghodusi \& Heidari, 2015).

Pada penelitian ini ditemukan pula data kualitatif berupa rasa ketakutan pasien terhadap munculnya sel kanker setelah pengobatan. Salah satu gejala psikologis yang paling sering muncul pada pasien 
pasca terapi kanker adalah adanya kekuatiran yang tinggi terhadap munculnya sel kanker pasca perawatan (Koch, Jansen, Brenner, \& Arndt, 2013).

Responden juga menyatakan kesedihannya akibat tidak bekerja lagi, sehingga menyebabkan kondisi finansial menurun secara drastis. Penelitian terhadap 1.433 pasien kanker diperoleh hasil terdapat $80 \%$ pasien yang menyatakan berhenti bekerja selama menderita kanker 1 hingga 5 tahun(Short, Vasey, \& Tunceli, 2005). Gejala sisa akibat kanker sepertidepresi, gangguan kognitif, kelelahan, dan masalah mobilitas, dapat mengganggu pekerjaan(Duijts et al., 2014). Terkait dengan permasalahan finansial yang muncul sebagai stresor pada penelitian ini, sebuah penelitian memberikan hasil yang menguatkan yaitu menyebutkan bahwa wanita dengan kanker payudara menunjukkan adanya perubahan pada 4 domain yaitu finansial, emosional, kepuasan seksual dan prospek masa depan (Sharma \& Purkayastha, 2017).

\section{Mekanisme Koping}

Pada penelitian ini mekanisme koping maladaptif dialami oleh responden pada kelompok kemoradioterapi.Manajemen terapi kanker yang kompleks berupa kombinasi kemoterapi dan radiasi memiliki efek samping yang lebih berat. Responden yang menerima kemoradioterapi sejumlah $>\quad 85 \%$ mengalami esophagitis dan harus dirawat di rumah sakit, dan juga mengalami infeksi (Strøm et al., 2013). Efek samping berupa fatigue juga menyebabkan stres fisik yang terjadi pada mayoritas pasien kanker. Terdapat $30-60 \%$ pasien melaporkan fatiguesedang hingga berat selama proses perawatan(Bower, 2014). Penelitian lain menyebutkan pula sejumlah 50\% pasien kanker yang menjalani terapi kanker mengalami fatigue pada tingkat berat, $43.3 \%$ fatigue tingkat sedang dan hanya $6.7 \%$ mengalami fatigue tingkat ringan (Werdani, 2018).

Stresor yang komplek akibat efek samping terapi memberikan tantangan tersendiri bagi pasien untuk mengelolanya.Pengelolaan stresor dalam bentuk mekanisme koping yang dilakukan oleh pasien tergantung dari diri sendiri dan support system yang ada, semakin baik seseorang mengelola stresornya, maka semakin baik pula mekanisme koping yang dilakukan, begitu juga sebaliknya. Dalam penelitian ini mekanisme koping maladaptif yang dilakukan oleh sebagian besar responden berdasarkan data kualitatif berupa kurangnya kemampuan 
dalam berpikir positif, kurangnya berbagi masalah dengan orang lain dan mengedepankan emosi. Penelitian pada 62 pasien kanker menyebutkan bahwa mekanisme koping yang ditunjukkan oleh responden meliputi anxious preoccupation, semangat juang, dan adanya ketidakberdayaan\& keputusasaan(Cieślak et al., 2012). Penelitian lain juga mengungkapkan hal yang serupa yaitu penelitian terhadap 80 pasien kanker disimpulkan bahwa mayoritas pasien kanker menggunakan strategi koping yang berfokus pada emosi dan mereka umumnya menggunakan subskala mengatasi masalah secara konfrontatif, menghindar/ melarikan diri dan mencari dukungan sosial, sementaramereka hampir tidak menggunakan subskala pengendalian diri, menerima tanggung jawab, penyelesaian masalah yang direncanakan, dan penilaian positif(Ahadi, Delavar, \& Rostami, 2014).

Timbulnya mekanisme koping maladatif pada kelompok kemoradioterapi dapat dikaitkan erat dengan gender yaitu mayoritas didominasi oleh responden perempuan sebesar 83.3\%. Penelitian yang dilakukan kepada wanita yang terdiagnosis Polycystic Ovary Syndrome memiliki koping pasif yang merupakan strategi maladaptif yang terkait dengan gejala kecemasan, depresi dan kualitas hidup yang terganggu(Benson et al., 2010). Durasi menderita sakit juga menjadi faktor yang memicu timbulnya mekanisme koping maladaptif akibat individu masih berada pada fase denial.Pada penelitian ini kelompok kemoradioterapi mayoritas respondennya baru terdiagnosa penyakit kanker $<1$ tahun yaitu sebesar 58.4\%.Denial atau penyangkalan pada pasien dengan penyakit serius dapat terjadi saat masih dalam pemeriksaan dan pada saat baru terdiagnosis serta munculnya tanda-tanda keseriusan penyakit fisik, hal ini diperparah pada saat pasien menjadi sadar bahwa kematian mungkin sudah dekat (Chandra \& Desai, 2007).

Berdasarkan hasil penelitian ini pada kelompok kemoterapi dan kelompok radiasi justru didominasi oleh responden yang memiliki mekanisme koping adaptif. Berdasarkan hasil data kualitatif yang diperoleh mayoritas responden yang memiliki mekanisme koping adaptif memiliki sikap yang lebih religious dan memiliki hubungan yang lebih baik dengan pendampingnya. Hal ini dapat dihubungkan dengan usia responden yang mayoritas pada kelompok kemoterapi dan radiasi berada pada rentang usia $56-65$ tahun. Pada usia 50 tahunan atau disebut dengan middle adulthood memiliki 
pengaturan emosi adaptif yang lebih baik (Zimmermann \& Iwanski, 2014). Faktor lain yang dapat menyebabkan timbulnya mekanisme koping adaptif pada kelompok kemoterapi dan radiasi adalah lama menderita sakit, yaitu terdapat sejumlah $16.7 \%$ pada kelompok kemoterapi dan 12.5\% pada kelompok radiasi yang respondennya telah terdiagnosa penyakit kanker pada kurun waktu 2 sampai $<3$ tahun. Durasi menderita sakit dapat menyebabkan individu menjadi lebih adaptif terhadap situasi sekalipun individu tersebut merasakan stres yang berat. Penelitian terhadap 579 pasien dengan nyeri kronis didapatkan hasil bahwa pengalaman penyakit dapat meningkatkan intensitas dan kedalaman hidup, sehingga dapat menyebabkan pasien memiliki strategi koping yang adaptif(Büssing, Ostermann, Neugebauer, \& Heusser, 2010). Hasil review terhadap 22 artikel mendapatkan suatu simpulan bahwa terdapat mekanisme koping yang dominan pada pasien dan keluarga penderita kanker yaitu mencari dukungan sosial, mengandalkan Tuhan dan bersikap positif (Mukwato et al., n.d.).

\section{Pengaruh tingkat stres terhadap mekanisme koping}

Berdasarkan hasil uji statistik dengan regresi ordinal terbukti bahwa pada ketiga kelompok tingkat stres memberikan pengaruh yang bermakna terhadap mekanisme koping dengan nilai $\mathrm{p}$ pada ketiga kelompok $<0.05$. Besarnya pengaruh tingkat stres terhadap mekanisme koping berdasarkan nilai pseudo R-Nagelkerke didapatkan hasil yang bervariasi yaitu pada kelompok kemoterapi menunjukkan besarnya pengaruh adalah $62.1 \%$, pada kelompok radiasi $59.7 \%$ dan pada kelompok kemoradioterapi $73.7 \%$. Pada saat individu sedang dalam keadaan stres maka individu tersebut dapat melakukan gaya koping yang berfokus pada masalah yaitu perilaku langsung untuk mengubah atau memodifikasi kondisi yang mengancam dan gaya koping yang berfokus pada emosi (Ho, Chan, \& Ho, 2004).

Penelitian terhadap 80 pasien menyatakan bahwa pasien dalam situasi stres lebih sering menggunakan strategi koping berupa penghindaran dan penolakan serta memiliki lebih banyak kesulitan dalam menemukan aspek positif dari peristiwa stres tersebut (Orzechowska, Zajączkowska, Talarowska, \& Gałecki, 2013). Penelitian terhadap 74 pasien kanker menyebutkan bahwa responden 
lebih banyak memiliki dysfunctional coping dibandingkan dengan responden yang sehat secara fisik (Aydogan et al., 2016).

\section{KESIMPULAN}

Manajemen terapi kanker baik kemoterapi, radiasi maupun kemoradioterapi menyebabkan pasien mengalami stres dengan tingkatan yang bervariasi dari tingkat stres sedang sampai berat.Tingkat stres yang timbul akibat manajemen terapi kanker memberikan pengaruh yang bermakna pada pasien dalam mengambil keputusan pengelolaan stres dalam bentuk mekanisme koping adaptif yang didominasi pada kelompok kemoterapi dan radiasi serta mekanisme koping maladaptif yang mayoritas dilakukan oleh responden pada kelompok kemoradioterapi.

\section{SARAN}

Perlu adanya pendekatan intervensi keperawatan untuk membantu pasien kanker yang menjalani terapi kanker dalam memanajemen stress dan kecemasan, sehingga dapat menghasilkan mekanisme koping yang adaptif.

\section{REFERENSI}

Ahadi, H., Delavar, A., \& Rostami, A. M. (2014). Comparing Coping Styles in Cancer Patients and Healthy Subjects. Procedia - Social and
Behavioral Sciences, 116, 3467-3470. https://doi.org/10.1016/j.sbspro.20 14.01.785

Aslam, M. S., Naveed, S., Ahmed, A., Abbas, Z., Gull, I., \& Athar, M. A. (2014). Side Effects of Chemotherapy in Cancer Patients and Evaluation of Patients Opinion about Starvation Based Differential Chemotherapy. Journal of Cancer Therapy. https://doi.org/10.4236/jct.2014.58 089

Aydogan, U., Doganer, Y., Komurcu, S., Ozturk, B., Ozet, A., \& Saglam, K. (2016). Coping attitudes of cancer patients and their caregivers and quality of life of caregivers. Indian Journal of Palliative Care, 22(2), 150. https://doi.org/10.4103/09731075.179598

Badan Penelitian dan Pengembangan Kesehatan. (2018). Hasil Utama Riskesdas 2018. Jakarta.

Benson, S., Hahn, S., Tan, S., Janssen, O. E., Schedlowski, M., \& Elsenbruch, S. (2010). Maladaptive coping with illness in women with polycystic ovary syndrome. Journal of Obstetric, Gynecologic, and Neonatal Nursing: JOGNN, 39(1), 37-45. https://doi.org/10.1111/j.15526909.2009.01086.x

Bongers, M. L., de Ruysscher, D., Oberije, C., Lambin, P., Uyl-de Groot, C. A., Belderbos, J., \& Coupé, V. M. H. (2017). MODEL-BASED COSTEFFECTIVENESS OF CONVENTIONAL AND INNOVATIVE CHEMORADIATION IN LUNG CANCER. International Journal of Technology Assessment in Health Care, 33(6), 681-690. https://doi.org/10.1017/S02664623 17000939

Bower, J. E. (2014). Cancer-related fatigue-mechanisms, risk factors and treatments. Nature Reviews 
Clinical Oncology, 11(10), 597-609. https://doi.org/10.1038/nrclinonc. 2014.127

Büssing, A., Ostermann, T., Neugebauer, E. A., \& Heusser, P. (2010). Adaptive coping strategies in patients with chronic pain conditions and their interpretation of disease. BMC Public Health, 10(1), 507. https://doi.org/10.1186/14712458-10-507

Chandra, P., \& Desai, G. (2007). Denial as an experiential phenomenon in serious illness. Indian Journal of Palliative Care, 13(1), 8. https://doi.org/10.4103/09731075.37184

Cieślak, K., Pawlukiewicz, M., Gołąb, D., Konys, M., Kuśnierkiewicz, M., \& Kleka, P. (2012). Styles of coping with stress of cancer in patients treated with radiotherapy and expectations towards medical staff Practical implications. Reports of Practical Oncology and Radiotherapy: Journal of Greatpoland Cancer Center in Poznan and Polish Society of Radiation Oncology, 18(2), 61-66. https://doi.org/10.1016/j.rpor.2012. 10.006

Duijts, S. F. A., van Egmond, M. P., Spelten, E., van Muijen, P., Anema, J. R., \& van der Beek, A. J. (2014). Physical and psychosocial problems in cancer survivors beyond return to work: a systematic review. PsychoOncology, 23(5), 481-492. https://doi.org/10.1002/pon.3467

Ferlay, J., Soerjomataram, I., Dikshit, R., Eser, S., Mathers, C., Rebelo, M., ... Bray, F. (2015). Cancer incidence and mortality worldwide: Sources, methods and major patterns in GLOBOCAN 2012. International Journal of Cancer, 136(5), E359-E386. https://doi.org/10.1002/ijc.29210

Geng, C., Paganetti, H., \& Grassberger, C. (2017). Prediction of Treatment Response for Combined Chemo- and Radiation Therapy for NonSmall Cell Lung Cancer Patients Using a Bio-Mathematical Model. Scientific Reports, 7(1), 13542. https://doi.org/10.1038/s41598017-13646-z

Ghodusi, M., \& Heidari, M. (2015). The relationship between body esteem and hope and mental health in breast cancer patients after mastectomy. Indian Journal of Palliative Care, 21(2), 198. https://doi.org/10.4103/09731075.156500

Ho, R. T. H., Chan, C. L. W., \& Ho, S. M. Y. (2004). Emotional control in Chinese female cancer survivors. Psycho-Oncology, 13(11), 808-817. https://doi.org/10.1002/pon.799

İzci, F., İlgün, A. S., Findıklı, E., \& Özmen, V. (2016). Psychiatric Symptoms and Psychosocial Problems in Patients with Breast Cancer. The Journal of Breast Health, 12(3), 94-101. https://doi.org/10.5152/tjbh.2016. 3041

Kang, H.-J., Bae, K.-Y., Kim, S.-W., Shin, H.-Y., Shin, I.-S., Yoon, J.-S., \& Kim, J.-M. (2017). Impact of Anxiety and Depression on Physical Health Condition and Disability in an Elderly Korean Population. Psychiatry Investigation, 14(3), 240-248. https://doi.org/10.4306/pi.2017.14. 3.240

Koch, L., Jansen, L., Brenner, H., \& Arndt, V. (2013). Fear of recurrence and disease progression in long-term ( $\geq 5$ years) cancer survivors-a systematic review of quantitative studies. Psycho-Oncology, 22(1), 1-11. https://doi.org/10.1002/pon.3022

Martin, O. A., Anderson, R. L., Russell, P. A., Ashley Cox, R., Ivashkevich, A., Swierczak, A., ... MacManus, M. P. (2014). Mobilization of Viable Tumor Cells Into the Circulation During Radiation Therapy. 
International Journal of Radiation Oncology*Biology*Physics, 88(2), 395403.

https://doi.org/10.1016/j.ijrobp.20 13.10.033

Moreno, A. C., Zhang, N., Giordano, S., Komaki, R. U., Liao, Z., Nguyen, Q. N., ... Lin, S. H. (2017). Comparative Effectiveness of Chemotherapy Alone Versus Chemotherapy and Radiation Therapy for Patients with Stage IV Esophageal Cancer. International Journal of Radiation Oncology*Biology*Physics, 99(2), E172E173.

https://doi.org/10.1016/j.ijrobp.20 17.06.1014

Mukwato, K., Mweemba, P., Makukula, M., \& Makoleka, M. (n.d.). Medical journal of Zambia.Medical Journal of Zambia (Vol. 37). [Associated Reviews Ltd.]. Retrieved from https://www.ajol.info/index.php/m $\mathrm{jz} /$ article/view/75653

National Cancer Institute. (2015). Cancer Staging - National Cancer Institute. Retrieved from https://www.cancer.gov/aboutcancer/diagnosis-staging/staging

Nikbakhsh, N., Moudi, S., Abbasian, S., \& Khafri, S. (2014). Prevalence of depression and anxiety among cancer patients. Caspian Journal of Internal Medicine, 5(3), 167-170. Retrieved from http://www.ncbi.nlm.nih.gov/pub med/25202445

Nipp, R. D., El-Jawahri, A., Fishbein, J. N., Eusebio, J., Stagl, J. M., Gallagher, E. R., ... Temel, J. S. (2016). The relationship between coping strategies, quality of life, and mood in patients with incurable cancer. Cancer, 122(13), 2110-2116. https://doi.org/10.1002/cncr.30025

Orzechowska, A., Zajączkowska, M., Talarowska, M., \& Gałecki, P. (2013). Depression and ways of coping with stress: a preliminary study. Medical Science Monitor: International Medical Journal of Experimental and Clinical Research, 19, 1050-1056.

https://doi.org/10.12659/MSM.889 778

Pearce, A., Haas, M., Viney, R., Pearson, S.-A., Haywood, P., Brown, C., \& Ward, R. (2017). Incidence and severity of self-reported chemotherapy side effects in routine care: A prospective cohort study. PLOS ONE, 12(10), e0184360. https://doi.org/10.1371/journal.po ne. 0184360

Rossi, L., Stevens, D., Pierga, J.-Y., Lerebours, F., Reyal, F., Robain, M., ... Rouzier, R. (2015). Impact of Adjuvant Chemotherapy on Breast Cancer Survival: A Real-World Population. PLOS ONE, 10(7), e0132853.

https://doi.org/10.1371/journal.po ne. 0132853

Scott, S. B., Sliwinski, M. J., \& BlanchardFields, F. (2013). Age differences in emotional responses to daily stress: the role of timing, severity, and global perceived stress. Psychology and Aging, 28(4), 1076-1087. https://doi.org/10.1037/a0034000

Seo, Y. M., Oh, H. S., Seo, W. S., \& Kim, H. S. (2006). [Comprehensive predictors of fatigue for cancer patients]. Taehan Kanbo Hakhoe Chi, 36(7), 1224-1231. Retrieved from http://www.ncbi.nlm.nih.gov/pub med/17211125

Sharma, N., \& Purkayastha, A. (2017). Factors affecting quality of life in breast cancer patients: A descriptive and cross-sectional study with review of literature. Journal of MidLife Health, 8(2), 75. https://doi.org/10.4103/jmh.JMH_ 15_17

Short, P. F., Vasey, J. J., \& Tunceli, K. (2005). Employment pathways in a 
large cohort of adult cancer survivors. Cancer, 103(6), 1292-1301. https://doi.org/10.1002/cncr.20912

Siegel, R., Naishadham, D., \& Jemal, A. (2012). Cancer statistics, 2012. CA: A Cancer Journal for Clinicians, 62(1), 10-29.

https://doi.org/10.3322/caac.20138 Strøm, H. H., Bremnes, R. M., Sundstrøm, S. H., Helbekkmo, N., Fløtten, Ø., \& Aasebø, U. (2013). Concurrent palliative chemoradiation leads to survival and quality of life benefits in poor prognosis stage III non-small-cell lung cancer: a randomised trial by the Norwegian Lung Cancer Study Group. British Journal of Cancer, 109(6), 1467-1475. https://doi.org/10.1038/bjc.2013.4 66

Werdani, Y. D. W. (2018). Effect of Cancer Related Fatigue tTo the Level of Independence of Cancer Patients and Caregiver Stress Level. Folia Medica Indonesiana, 54(2), 108. https://doi.org/10.20473/fmi.v54i2. 8859

Zimmermann, P., \& Iwanski, A. (2014). Emotion regulation from early adolescence to emerging adulthood and middle adulthood. International Journal of Behavioral Development, 38(2), 182-194.

https://doi.org/10.1177/016502541 3515405 